Article

\title{
Purchasing Green Products as a Means of Expressing Consumers' Uniqueness: Empirical Evidence from Peru and Bangladesh
}

\author{
Asghar Afshar Jahanshahi ${ }^{1,2}$ (I) and Jianfeng Jia ${ }^{3, *}$ \\ CENTRUM Católica Graduate Business School (CCGBS), Lima 15023, Peru \\ 2 Pontificia Universidad Católica del Perú (PUCP), Lima 15023, Peru; afshar@pucp.edu.pe \\ 3 School of Business Administration, Northeastern University, Shenyang 110169, China \\ * Correspondence: jfjia@mail.neu.edu.cn; Tel.: +86-024-8365-6383
}

Received: 11 September 2018; Accepted: 31 October 2018; Published: 6 November 2018

check for updates

\begin{abstract}
Does consumers' consumption of green products represent a method of satisfying their need for uniqueness? Does it enhance their self-image? In order to answer these questions, the present study attempts to understand how personal-level factors (such as the need for uniqueness) and product-level factors (such as self-expressive benefits) drive customers to go green. Survey-based data were collected from 247 customers in Bangladesh and 132 customers in Peru during 2017-2018. A hierarchical linear regression analysis was employed to test the proposed hypotheses. The results of this study highlight the important role played by the need for uniqueness as a major driver of green behavior among customers in both countries. Furthermore, self-expressive benefits were found to represent another reason on the part of customers in both Peru and Bangladesh for buying green products. This study hence contributes to the current literature by strengthening existing knowledge of the drivers of pro-environmental purchasing behavior in developing countries.
\end{abstract}

Keywords: green product purchase; self-expressive benefits; customers' need for uniqueness; Peru; Bangladesh; emerging countries

\section{Introduction}

Consumers differ in terms of their level of concern, commitment, and knowledge with regard to the natural environment $[1,2]$. Such variation leads to differences in customers' purchasing decisions [3,4]. Some consumers paid more attention to green products [5], but some others were resistant to participate in environmentally sustainable consumption [6,7]. Over the past two decades, public concern about preserving the biodiversity of the natural environment has increased significantly, particularly following the inauguration of Earth Day [8]. In the context of developed countries, recent studies have found increased customer awareness of environmental issues [9-12]. Despite this growth in scholarly attention concerning developed countries, there remains an incomplete understanding of why customers purchase eco-friendly products in developing and emerging countries $[11,13]$. In order to fill this research gap, in the present study, the effects of personal-level factors, such as the need for uniqueness, and product-level factors, such as self-expressive benefits, were tested in relation to customers' behavior regarding the consumption of green products in Peru and Bangladesh.

According to the most recent World Bank report, Peru, similar to many developing countries, is experiencing major environmental and natural challenges [14]. In the academic context of Peru, sustainability has received considerable attention on the part of scholars, especially in the fields of the natural sciences [15,16], human-environmental sciences [17-19], and ecological sciences [12,20]. Despite this growing research interest, we still have only limited understanding of the drivers of sustainable 
lifestyles in Peruvian society. Promoting individual sustainable lifestyles by means of encouraging green consumption has been introduced as a way of reducing environmental challenges [3,11,21-23]. Therefore, it is important to determine which types of people care the most about the environment and, relatedly, exhibit more sustainable lifestyles in Peru [24].

Bangladesh, as a developing country in Asia, experiences almost the same level of environmental challenges as Peru; for example, a high level of water and air pollution, the inefficient use and harvesting of natural resources, and an extremely high biodiversity loss rate [25]. Through establishing several training programs and introducing multiple sustainable development policies in recent years [26], the Bangladeshi government has attempted to enhance the commitment of manufacturers to achieving more sustainable production and more efficient resource utilization [27]. However, in such a corrupt business environment [28,29], manufacturing companies can easily find ways to ignore costly environmental obligations and commitments. By showing greater willingness to buy environmentally friendly products, customers can act as drivers of the green movement in Bangladeshi society. Therefore, it is important to identify those customers who exhibit more sustainable consumption behaviors.

Through the purchasing of green products, people are able to convey their willingness to consume in such a way that benefits society as a whole [30]. In other words, consuming green products represents a means of demonstrating a pro-environmental attitude, which is an important factor in formulating an individual's status and reputation within their community [31]. As the pursuit of uniqueness varies across individuals [32,33], different consumption patterns are generated by consumers' purchasing decisions [6].

The present study contributes to the current literature by identifying one personal factor and one product factor as the antecedents of green purchasing behavior in developing countries. The results of this study confirm that customers who seek to publicly display their uniqueness may conspicuously consume more green products. Extending the findings of previous studies [30,31], this study provides the first empirical evidence supporting the significant relationship between psychological benefits (such as self-expression) and the purchasing of green or environmentally friendly products. Furthermore, our study contributes to the rapidly growing body of literature concerning sustainable consumption behaviors by investigating for the first time the antecedents of the purchasing of green products in the Peruvian context. Our results highlight how individual differences in the pursuit of uniqueness can affect sustainable consumption behaviors, because those consumers with a high need for uniqueness are more willing to discuss the products they purchase with others [34]. The purchasing of more green products on the part of these types of customers can thus encourage green consumption behavior among the general population of a country.

\section{Literature Review and Hypothesis Development}

\subsection{Customers' Green Purchasing Behavior}

The purchasing behaviors of the consumers of green products have received considerable scholarly attention in recent years [8,30,35-37]. Specifically, green purchasing refers to a customer's general awareness of a given product's environmental advantages throughout the purchasing process, as well as to their purchasing decisions being environmentally oriented [38,39]. Green purchasing behavior can be explained, at least to a certain extent, as a person's willingness to buy products that are ecologically packaged, contain recycled materials, are bio-based, save energy, or have non-polluting features [39,40].

It is well accepted that not all peoples exhibit a similar level of attention to environmentally friendly products $[4,6]$. Consumers may believe that they can help to preserve nature and the environment by showing an interest in buying green products. Or they may find green products unfavorable and avoid participating in green consumption [4], because they may not have been aware of the positive or negative consequences of their consumption on the environment and society [41]. Or they may not have enough money and time to look for green products [4]. 
In fact, the majority of the environmental challenges (excess garbage; plastic and air pollution; wasted energy, nutrients, and materials) faced by every society stem from consumers' consumption behaviors [42]. By choosing more eco-friendly products, consumers can boost the green movement and hence aid in the preservation of the environment in their society. The purchasing of more green products on the part of customers can serve to motivate manufacturing companies to adopt more green marketing strategies and to produce more environmentally friendly products. In this regard, the authors of [43] have found that customers play an important role in fostering firms' environmental commitment.

Several personal-level factors are known to influence consumers' pro-environmental purchasing behavior. For instance, by collecting data from 312 Norwegian consumers, the authors of [40] showed that a consumer's emotions and level of environmental concern are important drivers of that consumer's green purchasing behavior. An empirical study conducted among 303 Malaysian retail customers proved that disseminating false or ambiguous environmental information diminished customers' green purchasing behavior [38]. Moreover, survey-based data obtained from 6010 customers in Hong Kong highlighted the important role played by both gender and age in explaining green purchasing behavior [44,45]. In general, females and younger customers showed a higher level of concern for the environment, and they exhibited higher levels of perceived environmental responsibility, when compared with males and older customers. Thus, having sufficient environmental knowledge is a determinate factor in relation to the purchasing of green products [46]. More importantly, the authors of [47] found that engagement with green purchasing behavior is highest among customers who strongly believe that their environmentally friendly actions will prove effective in combating environmental deterioration. In particular, consumers' intention to buy green products is higher when such consumers are aware that their consumption behavior can make a positive contribution to both sustainable development and environmental protection [48].

\subsection{Customers' Desire for Uniqueness}

According to the uniqueness theory [49], every person seeks to avoid both extreme dissimilarity and similarity with others in an attempt to establish their own uniqueness. Some individuals are more concerned about how they are perceived than others [50]. As such, these individuals try to appear as unique or different as possible, for example, by having strange tattoos, customized clothing, or controversial opinions [51]. A customer's need for uniqueness refers to the extent to which that customer pursues differentness during their acquisition, utilization, and disposition of consumer goods [32,33]. Such differentiations in terms of buying behavior can help a person to enhance their personal and social identities [52]. These behaviors or decisions are generally valued by the individual, as they make them feel distinct or different from others within their social context [53].

Tian et al. [33] and Tian and McKenzie [32] have suggested a consumer's need for uniqueness to encompass three dimensions. These dimensions include a customer's creative choices, their unpopular choices, and their similarity avoidance. A customer's creative choices reflect their willingness to choose those products that maximize their self-image and personal uniqueness in a socially acceptable way [54]. As for the second dimension of uniqueness, unpopular choices refer to the consumer's preference for using products that deviate, at least to some extent, from social norms [32]. Lastly, a customer's similarity avoidance refers to their disinterest in using widely accepted or commonly purchased products [55]. This type of customer ceases to purchase certain products once they become sufficiently popular with the general public.

\subsection{Self-Expressive Benefits for the Customer}

Customers usually consider the specific benefits of using a given brand or product, including the product's quality and price, as well as their degree of confidence that they will make the right decision [56,57]. Customers also buy products because of their perceived self-expressive benefits. In other words, the customer's purchasing motivation involves the desire to express their individual 
self, and it is thus a principal reason behind the customer's purchasing behavior [58]. Self-expressive benefits refer to the potential of a specific product or brand to become a symbol of the customer's self-image [30]. Hence, by buying such products and brands, the customer is able to express themselves within their social context [56,57].

In terms of green products, the authors of [30] were the first to propose and test the effects of customers' perception on the self-expressive benefits of purchasing green products. Their results were drawn from data concerning 726 consumers in a developed country (Spain), and their study did not identify significant correlation. As such, their results suggest that further empirical research should be conducted. In order to provide a more comprehensive understanding of the phenomenon of self-expressive benefits in the context of developing and emerging countries, the present study tested the effects of self-expressive benefits on the purchasing of green products by Peruvian and Bangladeshi consumers.

\subsection{The Customer's Desire for Uniqueness and the Purchasing of Green Products}

As we can see in the Figure 1, this study first hypothesized that individuals who desire uniqueness show a higher level of green product purchasing behavior. Individuals who exhibit a higher need for uniqueness have been characterized as demonstrating three decision types, namely creative choice, unpopular choice, and similarity avoidance. In the context of this study, customers who frequently make these types of decisions were expected to exhibit a preference for purchasing green products.

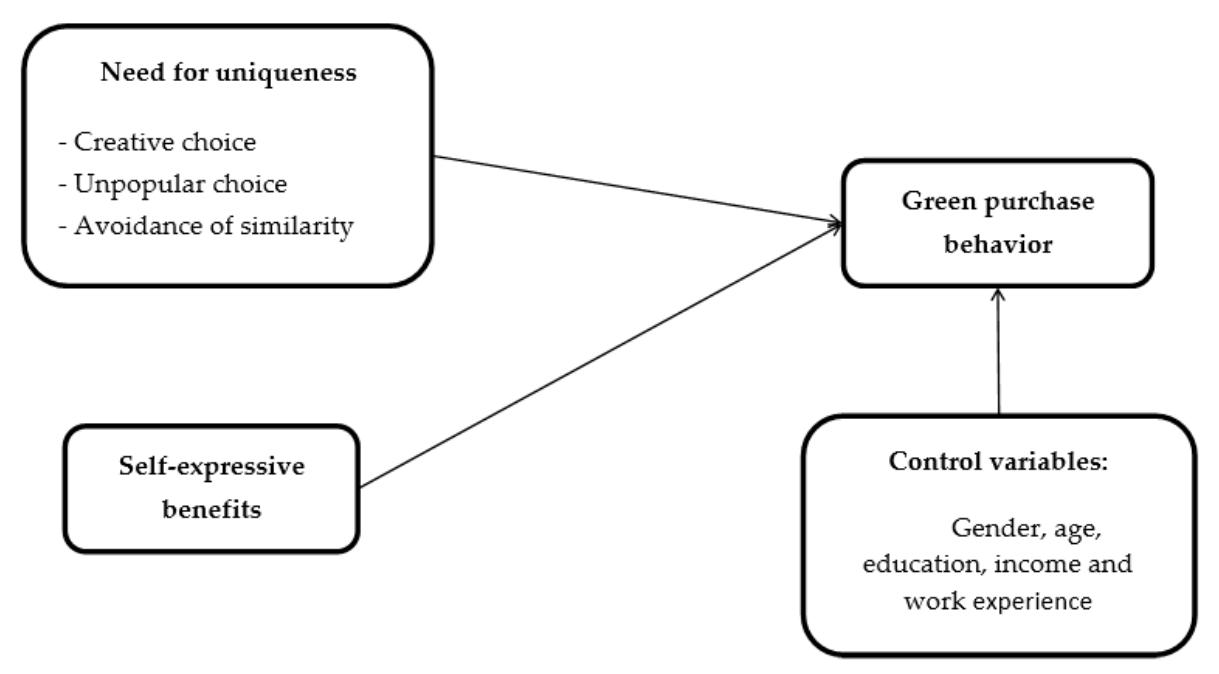

Figure 1. The conceptual model of the study.

A customer's creative choices are best manifested through their consumption selection, specifically through their purchasing of unique, new, and original market goods [32,50]. Based on the first hypothesis, a positive relationship was expected between the creative choices made by customers and their purchasing of green products. Lin and Huang [59] and Biswas and Roy [11] support this hypothesis, stating that novelty seeking represents one of the main reasons that customers choose to purchase green and eco-friendly products. Although green products are usually more expensive and of a lower quality than non-green products [31], survey-based data obtained from 431 female customers in the United States [60] revealed that the consumer's tendency to make creative choices enhances their adoption of new and sustainable retail products. Thus, this study hypothesizes the following:

H1. There is a positive relationship between a customer's creative choices and their green purchasing behavior.

The second hypothesis expected customers who make unpopular choices to exhibit a greater tendency to purchase green products. Despite an increase in environmental awareness being seen among customers in recent years [61,62], green products are still not commonly purchased, and not all customers have chosen to go green [63]. It was expected that customers who seek to purchase 
unpopular brands may show a greater willingness to buy novel green products. Similarly, the authors of $[51,64]$ found that the willingness to take risks in terms of consumer purchasing decisions is higher among individuals with a higher need for uniqueness. This could be accomplished through the purchasing of unpopular products or brands. Furthermore, Lynn and Harris [54] found that the preference for unique shopping venues was higher among customers who exhibited a higher need for uniqueness. Hence, this study hypothesizes the following:

H2. There is a positive relationship between a customer's unpopular choices and their green purchasing behavior.

The third hypothesis predicted that a customer's similarity avoidance enhances their green purchasing behavior. Previous studies have shown that customers do not pay equal attention to environmental issues when making purchasing decisions $[45,46,65]$. While buying green products arguably demonstrates a customer's concern for, and commitment to, the natural environment, it is also a means of displaying their dissimilarity to others within their community. Individuals who strongly avoid exhibiting similarity to others tend to establish a distinctive self-image by seeking out new products, acquiring scarce market commodities, and adopting novel and original goods [66]. Environmentally sustainable products are usually considered to be new and innovative products by customers [22,67]. Therefore, it was expected that customers who search for products that are not widely accessible to the market would show greater green purchasing behavior. Thus, this study hypothesizes the following:

H3. There is a positive relationship between a customer's similarity avoidance and their green purchasing behavior.

\subsection{Self-Expressive Consumer Benefits and the Purchasing of Green Products}

Previous studies have highlighted the importance of both social approval and affiliation in relation to consumers' purchasing decisions [68]. The products consumed by a given person often indicate their social status [30]. It is generally accepted that the majority of firms that pursue eco-friendly strategies do so in order to improve their market legitimacy and social approval [43,69]. A similar pattern was expected to exist on the individual level in terms of the purchasing of green products. Self-expression has long been considered one of the fundamental drivers of consumers' choices and preferences [70,71]. As a result of the increased level of environmental awareness seen in recent years $[2,72]$, consumers may consume these types of products so as to conspicuously display their concern for, and commitment to, the environment and, therefore, to achieve a higher level of social approval. Hence, this study's final hypothesis is the following:

H4. There is a positive relationship between a consumer's self-expressive benefits and their green purchasing behavior.

\section{Methodology}

\subsection{The Context of the Study}

The data used in this study were collected from consumers in two developing and emerging countries, namely Peru and Bangladesh. As has been the case in many developing countries, the desire to purchase green and eco-friendly products has grown significantly in both Peru and Bangladesh over the past decade. According to the recent Global Green Economy Index, Peru is ranked 33rd (score: 37.11 ) and Bangladesh is ranked 43rd (score: 34.61 ) out of 80 countries in terms of the green economy (please see https://dualcitizeninc.com/GGEI-2016.pdf). With regard to the Environmental Performance Index (EPI), Peru is ranked 64th out of 180 countries with a score of 61.92, while Bangladesh is ranked 179th with a score of 29.56 for the overall environmental performance (please see: https:/ / epi.envirocenter.yale.edu/2018/report/category/hlt). 


\subsection{Instrument Pre-Testing}

Although English is the most widely used foreign language in both Peru and Bangladesh, an English version of the present study was translated into the local languages (Spanish and Bengali, respectively) in order to enhance the accuracy of the responses. Following the approach of similar studies $[9,27,73]$, we have used a translation and back translation method, which is common in cross-cultural research [74]. First, one local language expert in each country translated the original survey items into the relevant local language. Then, we asked another person to back translate the Bengali and Spanish versions of the questionnaire. Lastly, by comparing the English survey with the translated ones, we modified any identified wording problems or ambiguities.

Prior to launching the questionnaires, the Bengali version was pre-tested among 53 master of business administration (MBA) students (from a public university) so as to ensure the scale, reliability, and validity of the instrument [75]. Additionally, the Spanish version of the survey was pre-tested among 20 postgraduate students. An exploratory factor analysis (EFA) confirmed the validity of the scale, while an acceptable Cronbach's alpha coefficient confirmed the scale's reliability in both countries. The Bangladeshi data have been collected from 247 customers in two large shopping malls in Dhaka, Bangladesh, through the drop-and-collect survey method [76]. We collected the Peruvian data from 132 customers in a big shopping mall in Lima, the capital city of Peru. In terms of the inclusion criteria, because of the absence of a sampling frame, we applied non-probability volunteer sampling in both countries [21].

\subsection{Sample Profile}

Among the Peruvian respondents, the majority were female (65.2\%), and their average age was 34 years. With regard to their level of education, 59.1\% had attended university. In terms of their monthly household income, $25.9 \%$ of respondents reported making below 500 USD per month, 35.4\% reported making 500-999 USD per month, 24.2\% reported making 1000-1499 USD per month, 10.5\% reported making 1500-1999 USD per month, and 3.8\% reported making more than 2000 USD per month. Furthermore, in terms of their work experience, approximately $37.9 \%$ of Peruvian respondents had $0-5$ years of experience, $49.2 \%$ had $6-10$ years of experience, $10.6 \%$ had $11-15$ years of experience, and only $2.3 \%$ had more than 16 years of work experience.

Among the Bangladeshi respondents, 38.1\% were male and $61.9 \%$ were female. In terms of their age, the majority of respondents fell within the age range of 25-35 years. With regard to their level of education, approximately $10.2 \%$ had a high school diploma, $23.1 \%$ had attended college, $21.1 \%$ had an undergraduate degree, $27.9 \%$ had attended graduate school, and $17 \%$ had a master's degree or higher. In terms of their monthly household income, 31.3\% of respondents reported making below 500 USD per month, 29.9\% reported making 500-999 USD per month, 22.4\% reported making 1000-1499 USD per month, 11.6\% reported making 1500-1999 USD per month, 4.1\% reported making 2000-2499 USD per month, and only 0.7\% reported making 2500 USD or more per month. Moreover, with regard to their work experience, approximately $30.6 \%$ of respondents had $0-5$ years of experience, $57.8 \%$ had $6-10$ years of experience, $8.8 \%$ had $11-15$ years of experience, and only $2.7 \%$ had more than 16 years of work experience.

\subsection{Measurements}

\subsubsection{Green Purchasing Behavior}

Five items were taken from the literature [8] to measure the purchasing behavior of customers with regard to the buying of green products. The Bangladeshi and Peruvian customers indicated the extent to which they engaged in the purchasing of green products on a five-point scale, which was anchored with (1) never and (5) always. The Cronbach's alpha coefficient for the scale was 0.938, which indicated the scale's reliability. Appendix A provides the specific wording of the scale items. 


\subsubsection{Self-Expressive Benefits}

Three items were adopted from the literature [30] to measure the expectations of the Bangladeshi and Peruvian customers in terms of the self-expressive benefits derived from eco-friendly and green products. A five-point scale anchored with (1) strongly disagrees and (5) strongly agree was used. The Cronbach's alpha score for this scale was 0.907 , which indicated the scale's reliability. The full wording of the items is shown in Appendix A.

\subsubsection{Consumers' Need for Uniqueness}

Twelve items from the literature [32] were used to measure the three established dimensions of the need for uniqueness (creative choice, unpopular choice, and avoidance of similarity) among the Bangladeshi and Peruvian consumers. When measuring the three dimensions, a five-point scale anchored with (1) strongly disagree and (5) strongly agree was used. The Cronbach's alpha score for the first four questions, which measured creative choice, was 0.904 . The Cronbach's alpha value for the second four items, which measured unpopular customer choice, was 0.882. Finally, the Cronbach's alpha value for the last four items, which measured similarity avoidance, was 0.893 . The obtained Cronbach's alpha values indicated the reliability of all the items. The full wording of the items is shown in Appendix A.

\subsubsection{Control Variables}

Previous studies have confirmed that gender differences [44], age [45], education level [46,77], income [47,78], and work experience [9,73] all contribute to green purchasing behavior. Hence, these demographic factors were included as control variables in the present study. The respondents were asked to select the option that most accurately represented their monthly household income from the following: (1) below 500 USD, (2) 500-999 USD, (3) 1000-1499 USD, (4) 1500-1999 USD, (5) 2000-2499 USD, or (6) 2500 USD or more. The respondents were then asked about their level of education, which was measured as follows: (1) high school, (2) attended college, (3) undergraduate degree, (4) attended graduate school, and (5) master's degree or higher. Lastly, the respondents provided information about their years of work experience by selecting from among the following options: (1) between $0-5$ years, (2) between 6-10 years, (3) between 11-15 years, and (4) more than 16 years.

\section{Results}

The descriptive data shown in Tables 1 and 2 demonstrate the positive correlation between the three dimensions of the need for uniqueness (in both data sets). As expected, the correlation between self-expressive benefits and green purchasing behavior was significant. All three dimensions of the need for uniqueness were found to be positively correlated with the dependent variable, namely green purchasing behavior.

Prior to testing the hypotheses, an EFA was conducted in order to verify whether a single or common method factor existed to account for the majority of variance in the findings $[79,80]$. The results indicated five distinct factors with eigenvalues greater than 1 . The Kaiser-Meyer-Olkin (KMO) measure of sampling adequacy was 0.869 , while the Bartlett's value was 0.000 . The first factor explained only $18.748 \%$ of the variance, although all five factors explained $72.096 \%$ of the total variance. 
Table 1. Means, standard deviations, and correlations (using only the Bangladeshi data).

\begin{tabular}{|c|c|c|c|c|c|c|c|c|c|c|c|}
\hline & Mean & SD & 1 & 2 & 3 & 4 & 5 & 6 & 7 & 8 & 9 \\
\hline 1. Gender & 1.619 & 0.487 & 1 & & & & & & & & \\
\hline 2. Age & 32.565 & 6.500 & $-0.444^{* *}$ & 1 & & & & & & & \\
\hline 3. Education & 3.184 & 1.255 & -0.12 & 0.017 & 1 & & & & & & \\
\hline 4. Working experiences & 1.830 & 0.706 & -0.13 & $0.460 * *$ & 0.09 & 1 & & & & & \\
\hline 5. Income & 2.293 & 1.183 & -0.007 & 0.065 & $0.171 *$ & 0.068 & 1 & & & & \\
\hline 6. Creative choice & 3.429 & 1.282 & -0.047 & 0.069 & $0.180 *$ & 0.034 & 0.06 & 1 & & & \\
\hline 7. Unpopular choice & 3.386 & 1.264 & -0.063 & 0.063 & $0.182 *$ & -0.026 & 0.08 & $0.465^{* *}$ & 1 & & \\
\hline 8. Avoidance of similarity & 3.357 & 1.293 & 0.122 & -0.081 & $0.230 * *$ & -0.152 & 0.03 & $0.504^{* *}$ & $0.462 * *$ & 1 & \\
\hline 9. Self-expressive & 3.231 & 1.323 & 0.021 & 0.033 & 0.112 & 0.055 & -0.006 & 0.126 & $0.276^{* *}$ & $0.278^{* *}$ & 1 \\
\hline 10. Green purchase & 3.414 & 1.251 & 0.074 & -0.013 & $0.352 * *$ & 0.102 & $0.218^{* *}$ & $0.457^{* *}$ & $0.447^{* *}$ & $0.526^{* *}$ & $0.358^{* *}$ \\
\hline
\end{tabular}

Table 2. Means, standard deviations, and correlations (using only the Peruvian data).

\begin{tabular}{|c|c|c|c|c|c|c|c|c|c|c|c|}
\hline & Mean & SD & 1 & 2 & 3 & 4 & 5 & 6 & 7 & 8 & 9 \\
\hline 1. Gender & 1.651 & 0.478 & 1 & & & & & & & & \\
\hline 2. Age & 34.747 & 11.037 & $-0.427^{* *}$ & 1 & & & & & & & \\
\hline 3. Education & 3.250 & 1.244 & -0.045 & 0.123 & 1 & & & & & & \\
\hline 4. Working experiences & 1.772 & 0.726 & -0.098 & 0.081 & 0.080 & 1 & & & & & \\
\hline 5. Income & 2.280 & 1.134 & -0.030 & 0.075 & $0.237^{* *}$ & 0.069 & 1 & & & & \\
\hline 6. Creative choice & 3.401 & 1.284 & -0.019 & 0.080 & 0.112 & 0.056 & -0.011 & 1 & & & \\
\hline 7. Unpopular choice & 3.373 & 1.297 & -0.001 & 0.027 & 0.164 & 0.034 & 0.058 & $0.435^{* *}$ & 1 & & \\
\hline 8. Avoidance of similarity & 3.395 & 1.299 & 0.089 & -0.001 & $0.216^{*}$ & -0.074 & -0.006 & $0.552 * *$ & $0.494^{* *}$ & 1 & \\
\hline 9. Self-expressive & 3.338 & 1.298 & -0.022 & 0.097 & 0.098 & 0.082 & 0.030 & $0.202 *$ & $0.273^{* *}$ & $0.330^{* *}$ & 1 \\
\hline 10. Green purchase & 3.407 & 1.257 & 0.111 & -0.135 & $0.314^{* *}$ & $0.187^{*}$ & 0.171 & $0.407^{* *}$ & $0.468^{* *}$ & $0.576^{* *}$ & $0.446^{* *}$ \\
\hline
\end{tabular}

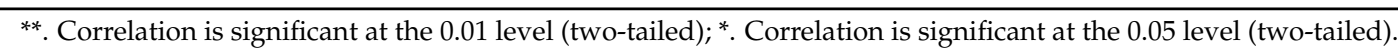


Table 2 presents the means, standard deviations, and correlation reliabilities among the variables using Peruvian data.

In each database, the hypotheses were tested in two steps using SPSS software (IBM, 24) and applying a hierarchical linear regression analysis. First, the effect of the control variables on the dependent variable was tested in both samples. As shown in Table 3 (Model 1 and Model 3), a non-significant relationship was found between customers' gender and their green purchasing behavior in both countries. The customers' age was not found to affect their green purchasing behavior in Bangladesh ( $\beta=-0.002 ;$ n.s.), although older customers in Peru exhibited a lower tendency to buy green products $(\beta=-0.026 ; p<0.01)$. The customers' educational level in both Bangladesh ( $\beta=0.332 ; p<0.001)$ and Peru $(\beta=0.302 ; p<0.001)$ was positively and significantly related to their green purchasing behavior. This means that customers with higher levels of education exhibited more environmental awareness and concern than customers with lower levels of education. Work experience was not found to have a significant effect on green purchasing behavior in Bangladesh ( $\beta=0.147$; n.s.), although Peruvian customers with more years of work experience exhibited a greater tendency to buy green products $(\beta=0.306 ; p<0.05)$. A positive and significant relationship was found between customers' income and their green purchasing behaviors $(\beta=0.166 ; p<0.05)$ in Bangladesh only. This means that Bangladeshi customers who fall into the upper-class income category pay more attention to green or environmentally friendly products than those customers in other income categories. We did not find a significant link between Peruvian customers' income and their green purchasing behaviors ( $\beta=0.113$; n.s.).

Table 3. Regression analysis (green purchasing behavior as the dependent variable). VIF-variance inflation factor.

\begin{tabular}{|c|c|c|c|c|c|c|}
\hline & \multicolumn{3}{|c|}{ Bangladesh } & \multicolumn{3}{|c|}{ Peru } \\
\hline & Model 1 & Model 2 & VIF & Model 3 & Model 4 & VIF \\
\hline 1. Gender & $0.307(0.171)$ & $\begin{array}{c}0.166 \\
(0.363)\end{array}$ & 1.327 & $0.200(0.399)$ & $0.080(0.650)$ & 1.243 \\
\hline 2. Age & $-0.002(0.813)$ & $\begin{array}{l}-0.013 \\
(0.370) \\
\end{array}$ & 1.595 & $-0.021+(0.077)$ & $-0.026^{* *}(0.003)$ & 1.259 \\
\hline 3. Educational level & $0.332^{* * *}(0.000)$ & $\begin{array}{l}0.177^{* *} \\
(0.008)\end{array}$ & 1.145 & $0.302^{* * *}(0.001)$ & $0.164 *(0.013)$ & 1.140 \\
\hline 4. Working Experiences & $0.147(0.244)$ & $\begin{array}{l}0.256^{*} \\
(0.046)\end{array}$ & 1.355 & $0.306 *(0.033)$ & $0.309^{* *}(0.005)$ & 1.051 \\
\hline 5. Income & $0.166 *(0.047)$ & $\begin{array}{l}0.162 * \\
(0.016)\end{array}$ & 1.043 & $0.113(0.223)$ & $0.136 *(0.052)$ & 1.071 \\
\hline 6. Creative choice & & $\begin{array}{l}0.184^{*} \\
(0.014)\end{array}$ & 1.521 & & $0.151 *(0.033)$ & 1.431 \\
\hline 7. Unpopular choice & & $\begin{array}{l}0.147^{*} \\
(0.049)\end{array}$ & 1.478 & & $0.087(0.238)$ & 1.548 \\
\hline 8. Avoidance of similarity & & $\begin{array}{c}0.263 * * * \\
(0.001)\end{array}$ & 1.692 & & $0.330^{* * *}(0.000)$ & 1.826 \\
\hline 9. Self-expressive benefits & & $\begin{array}{l}0.181^{* *} \\
(0.004)\end{array}$ & 1.139 & & $0.251^{* * *}(0.000)$ & 1.166 \\
\hline$R^{2}$ & 0.169 & 0.481 & & 0.174 & 0.557 & \\
\hline Adj. $R^{2}$ & 0.140 & 0.447 & & 0.142 & 0.524 & \\
\hline$F$ & $5.74^{* * *}$ & $14.095^{* * *}$ & & $5.322 * * *$ & $17.04^{* * *}$ & \\
\hline
\end{tabular}

In general, we did not find a consistent pattern in terms of the effects of the control variables on the green purchasing behaviors of customers in the two countries. Such inconsistency in our results indicates the need for further investigation.

The first hypothesis predicted a positive relationship between the creative choices of customers and their green purchasing behavior. Table 3 (Model 2) demonstrates that Bangladeshi customers' 
creative choices were positively and significantly related to their green purchasing behavior $(\beta=0.184$; $p<0.05$ ). As displayed in Table 2 (Model 4), a positive and significant relationship was also found between these two variables $(\beta=0.151 ; p<0.05)$ in the Peruvian sample. Therefore, the first hypothesis was confirmed by both datasets.

In terms of the second hypothesis, a positive relationship was expected between the customers' unpopular choices and their green purchasing behavior. Table 3 (Model 2) shows the relationship between Bangladeshi customers' unpopular choices and their green purchasing behavior to be positive and significant $(\beta=0.147 ; p<0.05)$. As also shown in Table 3 (Model 4), we found a non-significant relationship between Peruvian customers' unpopular choices and their green purchasing behavior ( $\beta=0.087$; n.s.). Therefore, the second hypothesis was only confirmed in the Bangladesh context.

The third hypothesis predicted a positive relationship between customers' avoidance of similarity and their green purchasing behavior. Table 3 (Model 2 and Model 4) demonstrates the similarity avoidance of customers in both Bangladesh $(\beta=0.263 ; p<0.001)$ and Peru $(\beta=0.330 ; p<0.001)$ to be positively and significantly related to their green purchasing behavior. Therefore, the third hypothesis was confirmed. Among the three dimensions of the need for uniqueness, customers' similarity avoidance had the strongest impact on their green purchasing behavior.

Lastly, a positive relationship was predicted between customers' self-expressive benefits and their green purchasing behavior. As shown in Table 3 (Model 2 and Model 4), customers' self-expressive benefits were positively and significantly related to their green purchasing behavior in both Bangladesh $(\beta=0.181 ; p<0.01)$ and Peru $(\beta=0.251 ; p<0.01)$. Thus, the final hypothesis was also confirmed. In order to ensure multicollinearity was not an issue for these analyses, the variance inflation factor (VIF) was calculated. Table 3 (Model 3 and Model 5) reveals all the VIF scores to be less than 2, thereby confirming that the research results did not suffer from multicollinearity. Figure 2 present the results of both studies.

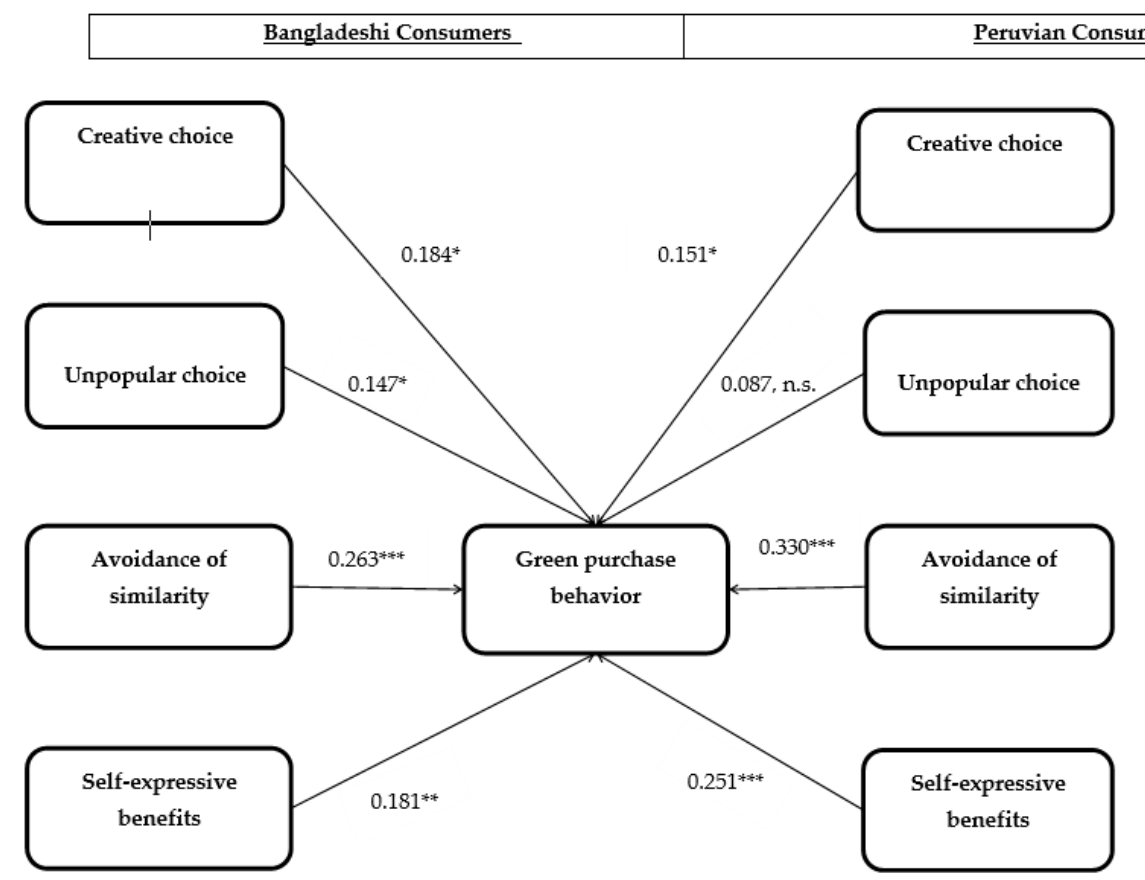

Figure 2. The relationship between creative choice, unpopular choice, avoidance of similarity, self-expressive benefits, and green purchase behavior Beta coefficients were for Model 2 and Model 4 (Table 2). ${ }^{*} p<0.05,{ }^{* *} p<0.01,{ }^{* * *} p<0.001$.

\section{Conclusions and Discussion}

The present study extends the previous research concerning the purchasing behavior of consumers who buy green products by incorporating personal- and product-level factors in the analysis. In general, 
the research findings were consistent with the findings of most earlier studies [31,63]. This study confirms that customers' beliefs are a powerful predictor of whether or not they will purchase green products. Recently, scholars have urged the expansion of the field of sustainability by focusing on the drivers of the eco-friendly behavior of customers in developing countries [35,43,81]. As our results were obtained from two developing countries, they facilitate a better understanding of the critical antecedents of consumers' green purchasing behaviors. In particular, our study was the first to identify those Peruvian customers who are more likely to act in an ecologically and environmentally friendly fashion. Customers play an important role in environmental protection [35], which means that changing customers' attitudes toward the environment is fundamental to any single country's green revolution [82]. Therefore, it is worth determining which types of customers most frequently use recycled paper and cans, durable products with low maintenance requirements, carpooling, water saving measures, and energy saving measures. Our findings can help the governments of both countries to accelerate their green movements, as well as to fine-tune their environmental programs.

In order to understand which customers engage the most in green activities, individual differences with regard to consumers' uniqueness and self-expressive benefits were considered.

In terms of the first hypothesis, a positive relationship between consumers' creative choices and their green purchasing behavior was found among the Bangladeshi and Peruvian customers. Customers who exhibited a higher level of creative choice were shown to be more concerned about their self-image in a social context [33]. The study's results hence suggest that buying green products helps customers to gain social approval.

Furthermore, the Bangladeshi data confirm that green purchasing behavior is more common among those customers who challenge the popular opinions and tastes of their social groups by selecting unpopular products or brands. The research findings confirm that customers who seek social differentness more often exhibit green purchasing behavior. This study thus provides further empirical evidence in support of Griskevicius's [31] study, reinforcing the notion that a key reason that customers buy green products is to make a statement about themselves. In general, a customer's need for uniqueness was found to be related to their desire for scarce, innovative, and customized products, as well as to their preference for unusual shopping venues $[54,64]$. As green products are known to offer some novelty and originality, their purchasers are able to satisfy their customer uniqueness needs.

Lastly, this study revealed that self-expressive benefits can motivate customers in developing countries to buy green products. In contrast with our results, after conducting 726 street interviews with customers in Spain (as a developed country), Hartmann and Apaolaza-Ibáñez [30] did not find sufficient evidence to support the existence of a positive relationship between consumers' self-expressive benefits and their purchasing of green products.

Changing consumers' behavior so that they act in a more environmentally friendly manner is a prerequisite for completing the green movement and green revolution in developing countries, such as Peru and Bangladesh [83]. In support of this idea, the authors of [84] found that approximately $40 \%$ of environmental pollution and degradation in Denmark results from the consumption activities of customers. The greater tendency of consumers to buy green products and services enhances the motivation of profit-driven enterprises to pursue greener strategies in their operations [43,85]. Therefore, various types of environmental programs and actions could be undertaken by both the Bangladeshi and Peruvian governments in order to enhance the environmental awareness of their respective populations; for instance, increasing media exposure of the issues, setting up more pro-environmental group activities, enforcing environmental protection by means of rigorous regulations, and encouraging more public discussion of important environmental issues.

\section{Limitations and Directions for Future Research}

As with many other studies examining the green purchasing behavior of consumers, this research study suffered from a number of limitations. First, our study focused on the antecedents of the consumers green buying decisions only, according to several scholars, there may still be some 
differences between respondents stated preference and revealed preference. While our survey-based research has made some contributions to the understanding the likely drivers of consumers' ecologically friendly behaviors, using a mixed-methods design (survey and interview) may provide a far more robust result. Second, the data were collected within a defined period of time (cross-sectional data). Future research studies could use longitudinal data to provide a deeper understanding of the investigated customer behaviors. Third, because of time and budget limitations, only two large malls in Dhaka, the capital of Bangladesh, and one shopping mall in Lima, Peru, were targeted for data collection in this study. Future studies should consider wider geographic boundaries. Forth, following the approach of the authors of $[21,86]$, because of the absence of a sampling frame, we only surveyed those customers who were interested in participating. Therefore, the use of non-probability sampling may serve to reduce the generalizability of our findings. However, some researchers strongly believe that this type of sample may yield similar results to probability samples [87]. Future research studies conducted in the contexts of Peru and Bangladesh could test the findings of our study using probability samples. Lastly, we targeted the most luxurious malls in Bangladesh and Peru. Usually, the visitors of these malls are customers with middle class and upper middle class income. We include the respondents' monthly income as a control variable, to increase the robustness of our findings. Future studies should include more diverse populations (in terms of income) in order to achieve more representative results. We should consider that not only people with middle and high level incomes pay attention to green products-the individual with low level income may also be environmentally friendly, because they are forced to recycle, to eat food from low-input backyard agriculture, or to purchase on local informal markets. Therefore, it is worth knowing how individuals in high-, middle-, and low-level income classes perceive consumption of green products. More specifically the question can be the following: whether purchasing green products is an available option for rich people, but a forced choice for poor people [88].

The majority of the available consumer theories are steeped in Western cultural values $[89,90]$. There hence exists a need to validate those theories with empirical evidence from countries less commonly investigated by scholars. Our study, especially in the context of Peru, has taken the initial steps required to determine what makes consumers go green, as well as to expand the literature concerning consumers' green purchasing behavior. We hope that our study will encourage other researchers in Peru to take the next steps and to identify different individual-level drivers of customers' green purchasing behavior. More customers adopting green behaviors will result in more businesses adopting sustainable business practices, which will eventually enhance the country's green movement. For instance, several physiological factors like individual environmental concern, openness to change, emotion, perceived environmental responsibility, and perceived effectiveness may predict the consumers green purchase behavior in the Peruvian context. By using more diverse designs, larger sample and quantitative analysis, future researchers can help to establish and enrich this field in the context of Latin America.

Author Contributions: Conceptualization, J.J. and A.A.J.; Methodology, J.J. and A.A.J.; Validation, A.A.J.; Formal Analysis, J.J. and A.A.J.; Investigation, A.A.J.; Resources, J.J.; Data Curation, A.A.J.; Writing-Original Draft Preparation, A.A.J; Writing-Review \& Editing, A.A.J and J.J.; Funding Acquisition, J.J.

Funding: This research was funded by National Natural Science Foundation of China (71672031), Humanities and Social Science Foundation of the Ministry of Education of China (16YJA630018), Fundamental Research Funds for the Central Universities of China (N160602001), Social Science Foundation of Liaoning in China (L17AGL005), Major Research Program of National Philosophy and Social Science Foundation(16AZD013).

Acknowledgments: We gratefully acknowledge the valuable time and cooperation given by Amitab Bhattacharjee throughout the data collection process, without his help, collection of data from Bangladeshi consumers wouldn't have been possible.

Conflicts of Interest: The authors declare no conflict of interest.

\section{Appendix A. Measurement Items}

Green Purchase Behavior adopted from the literature [8] 


\begin{tabular}{lc}
\hline & Factor Loading \\
\hline $\begin{array}{l}\text { 1. I make a special effort to buy paper and plastic products that are made from recycled } \\
\text { materials. }\end{array}$ & 0.796 \\
\hline 2. I have switched products for ecological reasons. & 0.779 \\
\hline $\begin{array}{l}\text { 3. When I have a choice between two equal products, I purchase the one less harmful to other } \\
\text { people and the environment. }\end{array}$ & 0.783 \\
\hline $\begin{array}{l}\text { 4. I make a special effort to buy household chemicals such as detergents and cleansing } \\
\text { solutions that are environmentally friendly. }\end{array}$ & 0.808 \\
\hline \begin{tabular}{l} 
5. I have avoided buying a product because it had potentially harmful environmental effects. \\
\hline \multicolumn{1}{c}{ Self-expressive benefits adopted from the literature [30] }
\end{tabular} & 0.851 \\
\hline $\begin{array}{l}\text { 1. In comparison with alternative products by buying green products, I can express my } \\
\text { environmental concern. }\end{array}$ & 0.846 \\
\hline $\begin{array}{l}\text { 2. In comparison with alternative products by buying green products, I can demonstrate to } \\
\text { myself and my friends that I care about environmental conservation. }\end{array}$ & 0.848 \\
\hline $\begin{array}{l}\text { 3. In comparison with alternative products by buying green products, my friends perceive me } \\
\text { to be concerned about the environment. }\end{array}$ &
\end{tabular}

Consumers' need for uniqueness adopted from the literature [32]

\begin{tabular}{ll}
\hline Creative Choice & 0.736 \\
$\begin{array}{l}\text { 1. I often combine possessions in such a way that I create a personal image that cannot be } \\
\text { duplicated. }\end{array}$ & 0.692 \\
\hline $\begin{array}{l}\text { 2. I often try to find a more interesting version of run-of-the-mill products because I enjoy } \\
\text { being original. }\end{array}$ & 0.787 \\
\hline $\begin{array}{l}\text { 3. I actively seek to develop my personal uniqueness by buying special products or brands. } \\
\text { 4. Having an eye for products that are interesting and unusual assists me in establishing a } \\
\text { distinctive image. }\end{array}$ & 0.851 \\
\hline Unpopular choice & 0.647 \\
\hline $\begin{array}{l}\text { 5. When it comes to the products I buy and the situations in which I use them, I have broken } \\
\text { customs and rules. }\end{array}$ & 0.745 \\
\hline 6. I have often violated the understood rules of my social group regarding what to buy or own. & 0.738 \\
\hline $\begin{array}{l}\text { 7. I have often gone against the understood rules of my social group regarding when and how } \\
\text { certain products are properly used. }\end{array}$ & 0.850 \\
\hline $\begin{array}{l}\text { 8. I enjoy challenging the prevailing taste of people I know by buying something they would } \\
\text { not seem to accept. }\end{array}$ & \\
\hline Avoidance of similarity & 0.771 \\
\hline 9. When a product I own becomes popular among the general population, I begin to use it less. \\
\hline $\begin{array}{l}\text { 10. I often try to avoid products or brands that I know are bought by the general population. } \\
\text { 11. As a rule, I dislike products or brands that are customarily bought by everyone. } \\
\text { 12. The more commonplace a product or brand is among the general population, the less }\end{array}$ & 0.729 \\
\hline
\end{tabular}

\section{References}

1. Schuhwerk, M.E.; Lefkoff-Hagius, R. Green or Non-Green? Does Type of Appeal Matter When Advertising a Green Product? J. Advert. 1995, 24, 45-54. [CrossRef]

2. Bang, H.-K.; Ellinger, A.E.; Hadjimarcou, J.; Traichal, P.A. Consumer concern, knowledge, belief, and attitude toward renewable energy: An application of the reasoned action theory. Psychol. Mark. 2000, 17, 449-468. [CrossRef] 
3. Young, W.; Hwang, K.; McDonald, S.; Oates, C.J. Sustainable consumption: Green consumer behaviour when purchasing products. Sustain. Dev. 2009, 18. [CrossRef]

4. Johnstone, M.-L.; Tan, L.P. Exploring the Gap Between Consumers' Green Rhetoric and Purchasing Behaviour. J. Bus. Ethics 2015, 132, 311-328. [CrossRef]

5. Aerni, P.; Scholderer, J.; Ermen, D. How would Swiss consumers decide if they had freedom of choice? Evidence from a field study with organic, conventional and GM corn bread. Food Policy 2011, 36, 830-838. [CrossRef]

6. Aerni, P. What is sustainable agriculture? Empirical evidence of diverging views in Switzerland and New Zealand. Ecol. Econ. 2009, 68, 1872-1882. [CrossRef]

7. Aerni, P.; Smyth, S.; Castle, D.; Phillips, P.W.B. The motivation and impact of organized public resistance against agricultural biotechnology. In Handbook on Agriculture, Biotechnology and Development; Smyth, S.J., Phillips, P.W.B., Castle, D., Eds.; Edward Elgar Publishing Ltd.: Cheltenham, UK, 2014; pp. 256-276, ISBN 9780857938350.

8. Kim, Y.; Choi, S.M. Antecedents of Green Purchase Behavior: An Examination of Collectivism, Environmental Concern, and Pce. Adv. Consum. Res. 2005, 32, 592-599.

9. Afshar Jahanshahi, A.; Brem, A.; Shahabinezhad, M. Does Thinking Style Make a Difference in Environmental Perception and Orientation? Evidence from Entrepreneurs in Post-Sanction Iran. Sustainability 2018, 10, 1546. [CrossRef]

10. Zhu, Q.; Sarkis, J.; Geng, Y. Green supply chain management in China: Pressures, practices and performance. Int. J. Oper. Prod. Manag. 2005, 25, 449-468. [CrossRef]

11. Biswas, A.; Roy, M. Green products: An exploratory study on the consumer behaviour in emerging economies of the East. J. Clean. Prod. 2015, 87, 463-468. [CrossRef]

12. Siche, R.; Pereira, L.; Agostinho, F.; Ortega, E. Convergence of ecological footprint and emergy analysis as a sustainability indicator of countries: Peru as case study. Commun. Nonlinear Sci. Numer. Simulat. 2010, 15, 3182-3192. [CrossRef]

13. Yadav, R.; Pathak, G.S. Young consumers' intention towards buying green products in a developing nation: Extending the theory of planned behavior. J. Clean. Prod. 2016, 135, 732-739. [CrossRef]

14. Liebenthal, A. Promoting Environmental Sustainability in Peru: A Review of the World Bank Group's Experience; World Bank: Washington, DC, USA, 2011.

15. Hurtado-Gonzales, J.L.; Bodmer, R.E. Assessing the sustainability of brocket deer hunting in the Tamshiyacu-Tahuayo Communal Reserve, northeastern Peru. Biol. Conserv. 2004, 116, 1-7. [CrossRef]

16. Ohl-Schacherer, J.; Shepard, G.H.; Kaplan, H.; Peres, C.A.; Levi, T.; Yu, D.W. The Sustainability of Subsistence Hunting by Matsigenka Native Communities in Manu National Park, Peru. Conserv. Biol. 2007, 21, 1174-1185. [CrossRef] [PubMed]

17. Bebbington, A.J.; Bury, J.T. Institutional challenges for mining and sustainability in Peru. Proc. Natl. Acad. Sci. USA 2009, 106, 17296-17301. [CrossRef] [PubMed]

18. Mark, B.G.; Bury, J.; McKenzie, J.M.; French, A.; Baraer, M. Climate Change and Tropical Andean Glacier Recession: Evaluating Hydrologic Changes and Livelihood Vulnerability in the Cordillera Blanca, Peru. Ann. Assoc. Am. Geogr. 2010, 100, 794-805. [CrossRef]

19. Orlove, B.; Podesta, G.P.; Broad, K.F. Environmental Citizenship in Latin America: Climate, Intermediate Organizations, and Political Subjects. Lat. Am. Res. Rev. 2011, 46, 115-140. [CrossRef]

20. Levi, T.; Shepard, G.H., Jr.; Ohl-Schacherer, J.; Peres, C.A.; Yu, D.W. Modelling the long-term sustainability of indigenous hunting in Manu National Park, Peru: Landscape-scale management implications for Amazonia. J. Appl. Ecol. 2009, 46, 804-814. [CrossRef]

21. Pham, T.H.; Nguyen, N.; Thu, T.; Phan, H.; Nguyen, N.T.; Thanh, N. Evaluating the purchase behaviour of organic food by young consumers in an emerging market economy. J. Strateg. Mark. 2018. [CrossRef]

22. Pickett-Baker, J.; Ozaki, R. Pro-environmental products: Marketing influence on consumer purchase decision. J. Consum. Mark. 2008, 25, 281-293. [CrossRef]

23. Gilg, A.; Barr, S.; Ford, N. Green consumption or sustainable lifestyles? Identifying the sustainable consumer. Futures 2005, 37, 481-504. [CrossRef]

24. Peña-Vinces, J.C.; Delgado-Márquez, B.L. Are entrepreneurial foreign activities of Peruvian SMNEs influenced by international certifications, corporate social responsibility and green management? Int. Entrep. Manag. J. 2013, 9, 603-618. [CrossRef] 
25. Hagerty, D.T. Bangladesh in 2007: Democracy Interrupted, Political and Environmental Challenges Ahead. Asian Surv. 2008, 48, 177-183. [CrossRef]

26. Rana, M.M.P. Urbanization and sustainability: Challenges and strategies for sustainable urban development in Bangladesh. Environ. Dev. Sustain. 2011, 13, 237-256. [CrossRef]

27. Afshar Jahanshahi, A.; Brem, A.; Bhattacharjee, A. Who takes more sustainability-oriented entrepreneurial actions? The role of entrepreneurs' values, beliefs and orientations. Sustainability 2017, 9, 1636. [CrossRef]

28. Zafarullah, H.; Siddiquee, N.A. Dissecting Public Sector Corruption in Bangladesh: Issues and Problems of Control. Public Organ. Rev. 2001, 1, 465-486. [CrossRef]

29. Mahmood, S.A.I. Public procurement and corruption in Bangladesh confronting the challenges and opportunities. J. Public Adm. Policy Res. 2004, 2, 103-111.

30. Hartmann, P.; Apaolaza-Ibáñez, V. Consumer attitude and purchase intention toward green energy brands: The roles of psychological benefits and environmental concern. J. Bus. Res. 2012, 65, 1254-1263. [CrossRef]

31. Griskevicius, V.; Tybur, J.M.; Van den Bergh, B. Going green to be seen: Status, reputation, and conspicuous conservation. J. Pers. Soc. Psychol. 2010, 98, 392-404. [CrossRef] [PubMed]

32. Ruvio, A.; Shoham, A.; Brenčič, M.M. Consumers' need for uniqueness: Short-form scale development and cross-cultural validation. Int. Mark. Rev. 2008, 25, 33-53. [CrossRef]

33. Tian, K.T.; Bearden, W.O.; Hunter, G.L. Consumers' Need for Uniqueness: Scale Development and Validation. J. Consum. Res. 2001, 28, 50-66. [CrossRef]

34. Cheema, A.; Kaikati, A.M. The Effect of Need for Uniqueness on Word of Mouth. J. Mark. Res. 2010, 47, 553-563. [CrossRef]

35. Han, H.; Hsu, L.-T.; Lee, J.-S. Empirical investigation of the roles of attitudes toward green behaviors, overall image, gender, and age in hotel customers' eco-friendly decision-making process. Int. J. Hosp. Manag. 2009, 28, 519-528. [CrossRef]

36. Rahbar, E.; Abdul Wahid, N. Investigation of green marketing tools' effect on consumers' purchase behavior. Bus. Strateg. Ser. 2011, 12, 73-83. [CrossRef]

37. Chen, Y.; Zhang, R.; Liu, B.; Chen, Y.; Zhang, R.; Liu, B. Joint Decisions on Production and Pricing with Strategic Consumers for Green Crowdfunding Products. Int. J. Environ. Res. Public Health 2017, 14, 1090. [CrossRef] [PubMed]

38. Goh, S.K.; Balaji, M.S. Linking green skepticism to green purchase behavior. J. Clean. Prod. 2016, 131, $629-638$. [CrossRef]

39. Mainieri, T.; Barnett, E.G.; Valdero, T.R.; Unipan, J.B.; Oskamp, S. Green Buying: The Influence of Environmental Concern on Consumer Behavior. J. Soc. Psychol. 1997, 137, 189-204. [CrossRef]

40. Koenig-Lewis, N.; Palmer, A.; Dermody, J.; Urbye, A. Consumers' evaluations of ecological packaging-Rational and emotional approaches. J. Environ. Psychol. 2014, 37, 94-105. [CrossRef]

41. Miller, D. Consumption and Its Consequences; Polity: London, UK, 2012; ISBN 0745661084.

42. Gan, C.; Yen Wee, H.; Ozanne, L.; Kao, T.-H. Consumers' purchasing behavior towards green products in New Zealand. Innov. Mark. 2008, 4, 93-102.

43. Afshar Jahanshahi, A.; Brem, A. Antecedents of Corporate Environmental Commitments: The Role of Customers. Int. J. Environ. Res. Public Health 2018, 15, 1191. [CrossRef] [PubMed]

44. Lee, K. Gender differences in Hong Kong adolescent consumers' green purchasing behavior. J. Consum. Mark. 2009, 26, 87-96. [CrossRef]

45. Lee, K. Opportunities for green marketing: Young consumers. Mark. Intell. Plan. 2008, 26, 573-586. [CrossRef]

46. Frick, J.; Kaiser, F.G.; Wilson, M. Environmental knowledge and conservation behavior: Exploring prevalence and structure in a representative sample. Pers. Individ. Differ. 2004, 37, 1597-1613. [CrossRef]

47. Straughan, R.D.; Roberts, J.A. Environmental segmentation alternatives: A look at green consumer behavior in the new millennium. J. Consum. Mark. 1999, 16, 558-575. [CrossRef]

48. Moser, A.K. Thinking green, buying green? Drivers of pro-environmental purchasing behavior. J. Consum. Mark. 2015, 32, 167-175. [CrossRef]

49. Snyder, C.R.; Fromkin, H.L. Uniqueness: The Human Pursuit of Difference; 1st ed.; Springer: Boston, MA, USA, 1980; ISBN 978-1-4684-3659-4.

50. Snyder, C.R.; Fromkin, H.L. Abnormality as a positive characteristic: The development and validation of a scale measuring need for uniqueness. J. Abnorm. Psychol. 1977, 86, 518-527. [CrossRef] 
51. Schumpe, B.M.; Herzberg, P.Y.; Erb, H.-P. Assessing the Need for Uniqueness: Validation of the German NfU-G scale. Pers. Individ. Differ. 2016, 90, 231-237. [CrossRef]

52. Kumar, A.; Lee, H.-J.; Kim, Y.-K. Indian consumers' purchase intention toward a United States versus local brand. J. Bus. Res. 2009, 62, 521-527. [CrossRef]

53. Nail, P.R. Toward an integration of some models and theories of social response. Psychol. Bull. 1986, 100, $190-206$. [CrossRef]

54. Lynn, M.; Harris, J. Individual differences in the pursuit of self-uniqueness through consumption. J. Appl. Soc. Psychol. 1997, 27, 1861-1883. [CrossRef]

55. Thompson, C.J.; Haytko, D.L. Speaking of Fashion: Consumers' Uses of Fashion Discourses and the Appropriation of Countervailing Cultural Meanings. J. Consum. Res. 1997, 24, 15-42. [CrossRef]

56. Aaker, D.A. Managing Brand Equity: Capitalizing on the Value of a Brand Name; 1st ed.; Free Press: New York, NY, USA, 1991; ISBN 0029001013.

57. Mudambi, S. Branding importance in business-to-business markets Three buyer clusters. Ind. Mark. Manag. 2002, 31, 525-533. [CrossRef]

58. Sirgy, M.J.; Lee, D.-J.; Johar, J.S.; Tidwell, J. Effect of self-congruity with sponsorship on brand loyalty. J. Bus. Res. 2008, 61, 1091-1097. [CrossRef]

59. Lin, P.-C.; Huang, Y.-H. The influence factors on choice behavior regarding green products based on the theory of consumption values. J. Clean. Prod. 2012, 22, 11-18. [CrossRef]

60. Lang, C.; Armstrong, C.M.; Liu, C. Creativity and sustainable apparel retail models: Does consumers' tendency for creative choice counter-conformity matter in sustainability? Fash. Text. 2016, 3, 24. [CrossRef]

61. Nguyen, T.N.; Lobo, A.; Greenland, S. Energy efficient household appliances in emerging markets: The influence of consumers' values and knowledge on their attitudes and purchase behaviour. Int. J. Consum. Stud. 2017, 41, 167-177. [CrossRef]

62. Nguyen, T.N.; Lobo, A.; Greenland, S. The influence of cultural values on green purchase behaviour. Mark. Intell. Plan. 2017, 35, 377-396. [CrossRef]

63. Han, H.; Hsu, L.-T.J.; Lee, J.-S.; Sheu, C. Are lodging customers ready to go green? An examination of attitudes, demographics, and eco-friendly intentions. Int. J. Hosp. Manag. 2011, 30, 345-355. [CrossRef]

64. Lalot, F.; Cantarella, M.; Zerhouni, O.; Joly, E.; Quiamzade, A.; Falomir-Pichastor, J.M.; Desrichard, O.; Bègue, L. Assessing Private and Public Need for Uniqueness: Validation of French Versions of the Need for Uniqueness (NfU) and Self-Attributed Need for Uniqueness (SANU) Scales. J. Pers. Assess. 2017, 1-11. [CrossRef] [PubMed]

65. Lee, S.; Koubek, R.J. The effects of usability and web design attributes on user preference for e-commerce web sites. Comput. Ind. 2010, 61, 329-341. [CrossRef]

66. Tepper, K.; Hoyle, R.H. Latent Variable Models of Need for Uniqueness. Multivar. Behav. Res. 1996, 31, 467-494. [CrossRef] [PubMed]

67. De Medeiros, J.F.; Ribeiro, J.L.D.; Cortimiglia, M.N. Success factors for environmentally sustainable product innovation: A systematic literature review. J. Clean. Prod. 2014, 65, 76-86. [CrossRef]

68. Simonson, I.; Carmon, Z.; Dhar, R.; Drolet, A.; Nowlis, S.M. Consumer research: In search of identity. Annu. Rev. Psychol. 2001, 52, 249-275. [CrossRef] [PubMed]

69. Molina-Azorín, J.F.; Claver-Cortés, E.; López-Gamero, M.D.; Tarí, J.J. Green management and financial performance: A literature review. Manag. Decis. 2009, 47, 1080-1100. [CrossRef]

70. Richins, M.L. Special Possessions and the Expression of Material Values. J. Consum. Res. 1994, 21, 522-534. [CrossRef]

71. Aaker, J.L. The Malleable Self: The Role of Self-Expression in Persuasion. J. Mark. Res. 1999, 36, 45-57. [CrossRef]

72. Nguyen, T.N.; Lobo, A.; Greenland, S. Pro-environmental purchase behaviour: The role of consumers' biospheric values. J. Retail. Consum. Serv. 2016, 33, 98-108. [CrossRef]

73. Gharleghi, B.; Afshar Jahanshahi, A.; Nawaser, K. The Outcomes of Corporate Social Responsibility to Employees: Empirical Evidence from a Developing Country. Sustainability 2018, 10, 698. [CrossRef]

74. Brislin, R.W. Back-translation for cross-cultural research. J. Cross. Cult. Psychol. 1970, 1, 185-216. [CrossRef]

75. DeSarbo, W.S.; Anthony Di Benedetto, C.; Sinha, I. Revisiting the Miles and Snow strategic framework: Uncovering interrelationships between strategic types, capabilities, environmental uncertainty, and firm performance. Strateg. Manag. J. 2005, 26, 47-74. [CrossRef] 
76. Kastanakis, M.N.; Balabanis, G. Between the mass and the class: Antecedents of the "bandwagon" luxury consumption behavior. J. Bus. Res. 2012, 65, 1399-1407. [CrossRef]

77. Jahanshahi, A.A.; Brem, A. Sustainability in SMEs: Top Management Teams Behavioral Integration as Source of Innovativeness. Sustainability 2017, 9, 1899. [CrossRef]

78. Kaufmann, H.R.; Panni, M.F.A.K.; Orphanidou, Y. Factors Affecting Consumers' Green Purchasing Behavior: An Integrated Conceptual Framework; Editura ASE: Bucharest, Romania, 2012; Volume 14, pp. 50-69.

79. Podsakoff, P.M.; MacKenzie, S.B.; Lee, J.-Y.; Podsakoff, N.P. Common method biases in behavioral research: A critical review of the literature and recommended remedies. J. Appl. Psychol. 2003, 88, 879-903. [CrossRef] [PubMed]

80. Podsakoff, P.M. Self-reports in organizational research: Problems and prospects. J. Manag. 1986, 12, 531-544. [CrossRef]

81. Mair, J.; Laing, J.H. Encouraging pro-environmental behaviour: The role of sustainability-focused events. J. Sustain. Tour. 2013, 21, 1113-1128. [CrossRef]

82. Chen, C.-C.; Chen, C.-W.; Tung, Y.-C. Exploring the Consumer Behavior of Intention to Purchase Green Products in Belt and Road Countries: An Empirical Analysis. Sustainability 2018, 10, 854. [CrossRef]

83. Lee, S.; Jeong, M. Impacts of "Green Movement" Cues of a Lodging Website on Customers' Emotions and Their Behaviors. In International CHRIE Conference-Refereed Track; Scholar Works: Amherst, MA, USA, 2011; Volume 8, pp. 1-30.

84. Grunert, S.C. Everybody Seems Concerned About the Environment: But Is This Concern Reflected in (Danish) Consumers' Food Choice? ACR Eur. Adv. 1993, E-01, 428-433.

85. Chan, R.Y.K. Determinants of Chinese Consumers' Green Purchase Behavior; John Wiley \& Sons, Inc.: Hoboken, NJ, USA, 2001; Volume 18.

86. Ramayah, T.; Lee, J.W.C.; Mohamad, O. Green product purchase intention: Some insights from a developing country. Resour. Conserv. Recycl. 2010, 54, 1419-1427. [CrossRef]

87. Yeager, D.S.; Krosnick, J.A.; Chang, L.; Javitz, H.S.; Levendusky, M.S.; Simpser, A.; Wang, R. Comparing the Accuracy of RDD Telephone Surveys and Internet Surveys Conducted with Probability and Non-Probability Samples. Public Opin. Q. 2011, 75, 709-747. [CrossRef]

88. Campo, I.S.; Aerni, P.; Oniang'o, R.K. Europe and Africa: Addressing the food security challenges. In Creating Sustainable Bioeconomies the Bioscience Revolution in Europe and Africa; Virgin, I.E., Morris, J., Eds.; Routledge: Abington, UK, 2016; pp. 82-94.

89. Wong, N.Y.; Ahuvia, A.C. Personal Taste and Family Face: Luxury Consumption in Confucian and Western Societies. Psychol. Mark. 1998, 15, 423-441. [CrossRef]

90. Tse, D.K.; Belk, R.; Zhou, N. Becoming a Consumer Society: A Longitudinal and Cross-Cultural Content Analysis of Print Ads from Hong Kong, the People's Republic of China, and Taiwan. J. Consum. Res. 1989, 15, 457-472. [CrossRef]

(C) 2018 by the authors. Licensee MDPI, Basel, Switzerland. This article is an open access article distributed under the terms and conditions of the Creative Commons Attribution (CC BY) license (http://creativecommons.org/licenses/by/4.0/). 